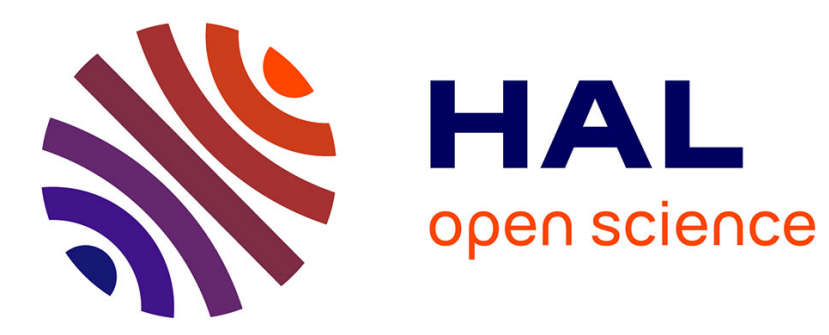

\title{
Multimeric Purinoceptor Detection by Bioluminescence Resonance Energy Transfer
}

Vincent Compan, François Rassendren

\section{To cite this version:}

Vincent Compan, François Rassendren. Multimeric Purinoceptor Detection by Bioluminescence Resonance Energy Transfer. Purinergic Signaling, pp.155-162, 2020, 10.1007/978-1-4939-9717-6_11. hal-02395187

\section{HAL Id: hal-02395187 \\ https://hal.science/hal-02395187}

Submitted on 12 Oct 2021

HAL is a multi-disciplinary open access archive for the deposit and dissemination of scientific research documents, whether they are published or not. The documents may come from teaching and research institutions in France or abroad, or from public or private research centers.
L'archive ouverte pluridisciplinaire $\mathbf{H A L}$, est destinée au dépôt et à la diffusion de documents scientifiques de niveau recherche, publiés ou non, émanant des établissements d'enseignement et de recherche français ou étrangers, des laboratoires publics ou privés. 


\title{
Multimeric purinoceptor detection by bioluminiscence resonance energy transfer
}

\author{
Vincent Compan $^{1,2}$ and François Rassendren ${ }^{1,2}$ \\ ${ }^{1}$ IGF, Univ. Montpellier, CNRS, INSERM, Montpellier, France. ${ }^{2}$ Labex ICST
}

\section{Summary}

Assays based on bioluminescence resonance energy transfer (BRET) provide a sensitive and simple method to study protein-protein interactions in live cells. Here we describe a protocol using BRET technique to investigate potential interactions between $\mathrm{P} 2 \mathrm{X}$ subunits. This approach combined with bimolecular fluorescence complementation (BiFC) can also be employed to determine the stoichiometry of heteromeric P2X receptors.

Key words: Bioluminescence, BRET, P2X, BiFC, stoichiometry, heteromer.

Running title: Characterization of $\mathrm{P} 2 \mathrm{X}$ receptor assembly by BRET

\section{Introduction}

Bioluminescence resonance energy transfer (BRET) is a naturally occurring phenomenon observed in some marine species such as Renilla reniformis where a nonradiative energy transfer is naturally observed between the Renilla luciferase (energy donor) and the Renilla green fluorescent protein (energy acceptor) [1,2]. This process 
has been adapted for the detection of protein-protein interactions by simply fusing one protein with the BRET donor and the other one with the BRET acceptor. Energy transfer efficiency depends on the orientation of the donor and the acceptor and is inversely proportional to the sixth power of distance between them. Different BRET donors and acceptors exist, but the most commonly used BRET donor is Renilla Luciefase (RLuc and its variants such as RLuc8) that catalyzes the oxidation of its substrate, coelenterazine, to produce light with a peak emission around $480 \mathrm{~nm}$. Emission spectra of RLuc overlaps well with the excitation spectra of YFP (and its variants such as Venus) making these fluorescent proteins suitable as BRET acceptor for RLuc. The main advantage of BRET over FRET (where donor and acceptor are fluorescent proteins) is that BRET does not require any external light excitation, improving signal to noise ratio and reducing cell damage induced by light excitation. The main limitation of BRET approach is due to the weak signals of BRET donors, although this limitation was recently partially overcame by the development by Promega of a new luciferase called NanoLuc that is much brighter than traditional RLuc BRET donor.

FRET approaches have been employed in the field of P2X receptors to analyze the architecture and size of $\mathrm{P} 2 \mathrm{X} 4$ receptors [3] and to study cytosolic gating motions in the $\mathrm{N}$ - and C-terminal domains of P2X2 [4]. Interactions between P2X2 receptors and other ligand-gated ion channels such as $\alpha 4 \beta 2$ nicotinic channels[5], $\alpha 6 \beta 4$ nicotinic channels [6] or $\mathrm{GABA}_{\mathrm{A}}$ ion channels [7] were also demonstrated and characterized using FRET technique. A specific FRET approach has also been developed in biosensors able to track activation of ATP-gated $\mathrm{P} 2 \mathrm{X}$ receptors [8].

BRET is historically more popular in the field of $\mathrm{G}$ protein coupled receptor and only few publications employed this approach for studying ion channels and more specifically P2X receptor. For instance, BRET was used to characterize the effect of 
carboxyl-terminal splicing on the physical interactions between the cytoplasmic tails of purinergic P2X2 receptors [9]. We also developed this approach to identify the interaction between $\mathrm{P} 2 \mathrm{X} 2$ and $\mathrm{P} 2 \mathrm{X} 5$ subunits, and to demonstrate that these two subunits can form heteromeric receptors with two different quaternary structures [10]. In this chapter, we describe a simple protocol that employ BRET approaches to study P2X subunits interactions. By combining this technique with Bimolecular Fluorescence Complementation (BiFC), BRET allows determining the stoichiometry of heteromeric $\mathrm{P} 2 \mathrm{X}$ receptors.

2. Materials

\subsection{Expression of the P2X tagged subunits in HEK293}

1 Transfection reagent Lipofectamine 2000 or equivalent can be used to transfect HEK293.

2 Complete cell media appropriate to the cell line in culture (for example, high glucose DMEM-Glutamax medium with 10\% of fetal calf serum for HEK293).

3 Opti-MEM culture media (Life Technologies).

4 Plasmids coding for the P2X subunits tagged with either RLuc8, or YFP or hemi YFP (YC or YN) (see Note 1).

\subsection{BRET recording using a plate reader}

196 well plate, white, flat and micro-clear bottom, cell culture treated, sterile with lids (see Note 2) for BRET recording. 
296 well plate, black, flat and micro-clear bottom, cell culture treated, sterile with lids (see Note 2) for fluorescence recording.

3 White backing tape to be stuck on the bottom of the 96 well plate the day of recording. It increases the luminescence signal by reflection.

4 A plate reader for luminescence recording equipped with two emission filters close to $480 \mathrm{~nm}$ and $535 \mathrm{~nm}$.

5 HBS solution: $147 \mathrm{mM} \mathrm{NaCl}, 2 \mathrm{mM} \mathrm{KCl}, 2 \mathrm{mM} \mathrm{CaCl}, 1 \mathrm{mM} \mathrm{MgCl} 2,10 \mathrm{mM}$ HEPES and $13 \mathrm{mM}$ D-glucose, $\mathrm{pH} 7.4$.

6 Multichannel pipettes.

7 Coelenterazine-h (see Note 3 ).

3. Methods

\subsection{General design of the experiment}

BRET occurs when the acceptor and the donor are in close proximity (typically, within $10 \mathrm{~nm}$ ) that makes this approach ideal for monitoring protein-protein interactions in living cells. However, several controls have to be performed to ensure the specificity of the BRET signal, especially in over-expression system where random collisions or nonspecific oligomerization might occur. As a general rule, we strongly recommend to include the following control:

1 Use non-transfected cells to determine background signal for luminescence recording.

2 A direct fusion between the BRET donor and the acceptor might be employed as a positive control. It will result in a strong BRET signal. 
3 Cells transfected with P2X-RLuc8 construct alone are necessary to calculate the net BRET signal. This will help to determine the 'BRET background' due to the partial overlap between donor and acceptor emission spectra.

4 BRET saturation curves must be performed (see Note 4). In this assay, a specific BRET signal will be characterized by a hyperbolic increase of the signal whereas random collisions are characterized by a linear increase of the BRET signal.

\subsection{HEK293 transfection and plating}

1 Cells are plated 24 hours before transfection in 6 well plate to obtain a $60-70 \%$ confluence on the day of transfection.

2 Transfection of HEK293 can be performed using Lipofectamine 2000 according to the manufacturer's instructions, using cDNA coding for BRET donor and acceptor (see Note 4), $100 \mu$ l Opti-MEM and $5 \mu 1$ Lipofectamine2000 per well.

3 Incubate cells with the transfection mixture for $4-5 \mathrm{~h}$ at $37^{\circ} \mathrm{C}$ and $5 \% \mathrm{CO}_{2}$, then remove transfection reagent containing media and split cells in 2 independent black and white 96 well plates (see Note 5).

4 Incubate cells for $36 \mathrm{~h}$ at $37^{\circ} \mathrm{C}$ and $5 \% \mathrm{CO}_{2}$, (see Note 6).

5 Perform BRET experiments.

\subsection{BRET and fluorescence recording using a plate reader}

5 Pre-warm the plate reader at $37^{\circ} \mathrm{C}$.

6 Set up the plate reader controlling software according to record fluorescence (see Note 7). 
7 Wash cells from the black plate twice with $100 \mu \mathrm{HBS}$ per well taking care not to detach cells.

8 Keep cells in $50 \mu 1$ of HBS per well.

9 Read the YFP fluorescence $(\lambda \mathrm{ex} \approx 500 \mathrm{~nm}, \lambda \mathrm{em} \approx 530 \mathrm{~nm})$ to determine expression of the BRET acceptor construction.

10 Set up the plate reader controlling software to record BRET signal (see Note 7 and Note 8).

11 Prepare a stock solution of coelenterazine-h at $25 \mu \mathrm{M}$ in HBS. Prepare enough volume of the stock solution in order to add $10 \mu \mathrm{l}$ per well to read.

12 Wash cells from the white plate twice with $100 \mu \mathrm{HBS}$ per well taking care not to detach cells.

13 Keep cells in $40 \mu$ of HBS per well.

14 Stick the white backing tape at the bottom of the plate.

15 Add $10 \mu \mathrm{l}$ of the stock coelenterazine-h per well to get a $5 \mu \mathrm{M}$ final concentration in 50 $\mu \mathrm{L}$ final volume.

16 Insert the plate in the plate reader.

17 Incubate for 4 minutes to allow the luminescence signal to reach a steady state (see Note 9).

18 Read the luminescence signal at $\approx 480$ (RLuc8 filter) $\mathrm{nm}$ and $\approx 535 \mathrm{~nm}$ (YFP filter); determine the integration time according to the sensitivity of the plate reader (see Note 7).

19 Record the luminescence signal at $480 \mathrm{~nm}$ and $535 \mathrm{~nm}$ in the same experimental conditions set above. Do not forget to use cells transfected with P2X-RLuc8 construct alone to calculate net BRET signal (see Note 10). 
20 Net BRET value, expressed in milliBRET units (or $\mathrm{mBU}$ ), can be determined with the following equation:

$$
\operatorname{BRET}(\mathrm{mBU})=\left(\left(\frac{\operatorname{Lum}(535 \mathrm{~nm})}{\operatorname{Lum}(480 \mathrm{~nm})}\right)^{P 2 X-R L u c 8}+\left(\frac{\operatorname{Lum}(535 \mathrm{~nm})}{\operatorname{Lum}(480 \mathrm{~nm})}\right)^{P 2 X-R L u c 8 \text { only }}\right) \times 1000
$$

21 For each condition of transfection, determine the ratio acceptor/donor by dividing the fluorescence obtained with the black plate by the luminescence measured at $480 \mathrm{~nm}$ in the white plate during BRET recording. Report these values (X axis) to the BRET value ( $\mathrm{Y}$ axis) to get a saturation curve. A specific BRET signal is characterized by a hyperbolic increase of the signal whereas random collisions are characterized by a linear increase of the BRET signal.

\section{Notes}

1 P2X subunits fused to YFP constructs are used to determine potential P2X subunit interactions. Hemi YFP constructs (YN or YC for N-term or C-term fragments of YFP respectively) are used to determine the stoichiometries of $\mathrm{P} 2 \mathrm{X}$ heteromeric receptors by combining BRET experiments and Bimolecular Fluorescence Complementation (BiFC).

2 Other format plate (i.e. 384 well plate) can be used depending on the assay and/or luminescence signal strength. Micro-clear bottom plate allows to visualize cells during the different steps of the experiment. Black and white plates are preferentially used to record fluorescence and luminescence signal, respectively. However, depending on the fluorescence or luminescence signal strength, any type of plate can be used indifferently.

3 Coelenterazines are poorly soluble in water and must be resuspended in ethanol or methanol at $1 \mathrm{mM}$ master stock solution. Keep this stock solution at $-20^{\circ} \mathrm{C}$ and protect 
it from light. For prolonged storage, resuspend coelenterazine in acidified ethanol (10 $\mathrm{ml}$ of ethanol and $200 \mu \mathrm{L}$ of $3 \mathrm{~N} \mathrm{HCl}$ ) and store at $-80^{\circ} \mathrm{C}$.

4 For BRET saturation-curve experiments, cells are co-transfected with a fixed amount of Rluc8 fusion cDNA and increasing amounts of YFP fusion cDNA (or YC and YN when combining BRET with BiFC assay). As a first try, $25 \mathrm{ng}$ of P2X-RLuc8 constructs might be combined to $0,10,20,50,100$ and $200 \mathrm{ng}$ of P2X-YFP (or YC/YN) constructs. Depending on the expression and the BRET signal, adjust the amount of cDNA.

5 Poly-L-ornithine coated plates might be used to prevent cell detachment. Two independent plates (black and white) are used to record fluorescence and luminescence signal, respectively.

6 For BRET/BiFC experiments, cells must be incubated at $30^{\circ} \mathrm{C}$ for $12 \mathrm{~h}$ before the reading to promote the complementation between hemi-YFP.

7 Exposure time and gain amplification of signals have to be determined to get the best signal/background ratio. Integration time must be adjusted to get the widest dynamic range and the best sensitivity for a given plate reader. For BRET recording, the integration time of the luminescence signal has to be the lowest. These values of integration time will stay approximately the same for each experiment and will just need to be adjusted depending on the transfection efficiency.

8 Detection of the luminescence signal within the filters of RLuc8 and YFP in a given well have to be recorded successively (ideally simultaneously) before recording the next well.

9 During the first 4 minutes following coelenterazine-h addition, luminescence signal will increase exponentially and might cause inappropriate BRET value (especially if the exposure time for each filter is $\geq 1 \mathrm{~s}$ ). Thus, it is recommended to wait for the luminescence signal to reach a plateau. 
10 For a given set of filters, plate reader and experimental conditions, the ratio $\left(\frac{\operatorname{Lum}(535 \mathrm{~nm})}{\operatorname{Lum}(480 \mathrm{~nm})}\right)^{P 2 X-R L u c 8 \text { only }}$ for the donor only will stay approximatively the same during each experiment and will just have to be determined once.

A
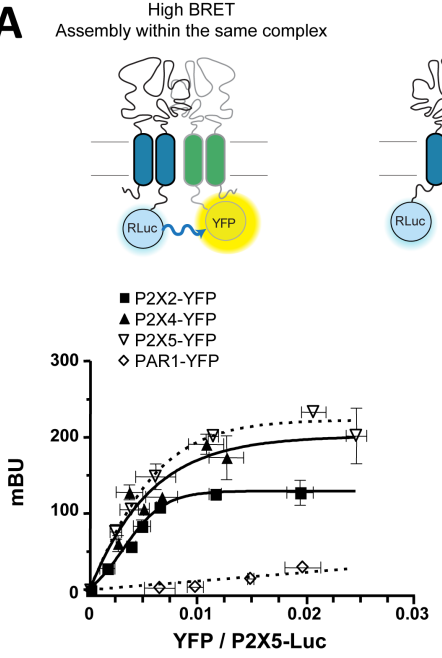

B
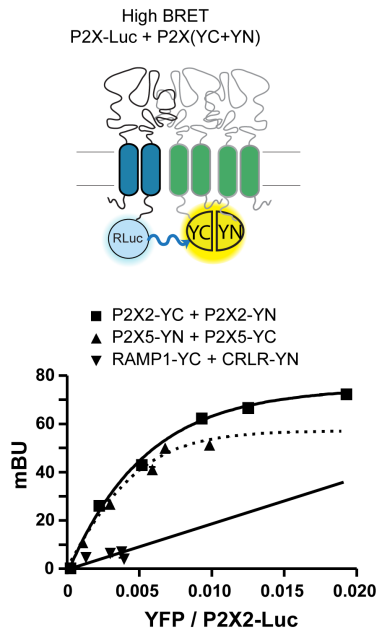

YFP / P2X2-Luc
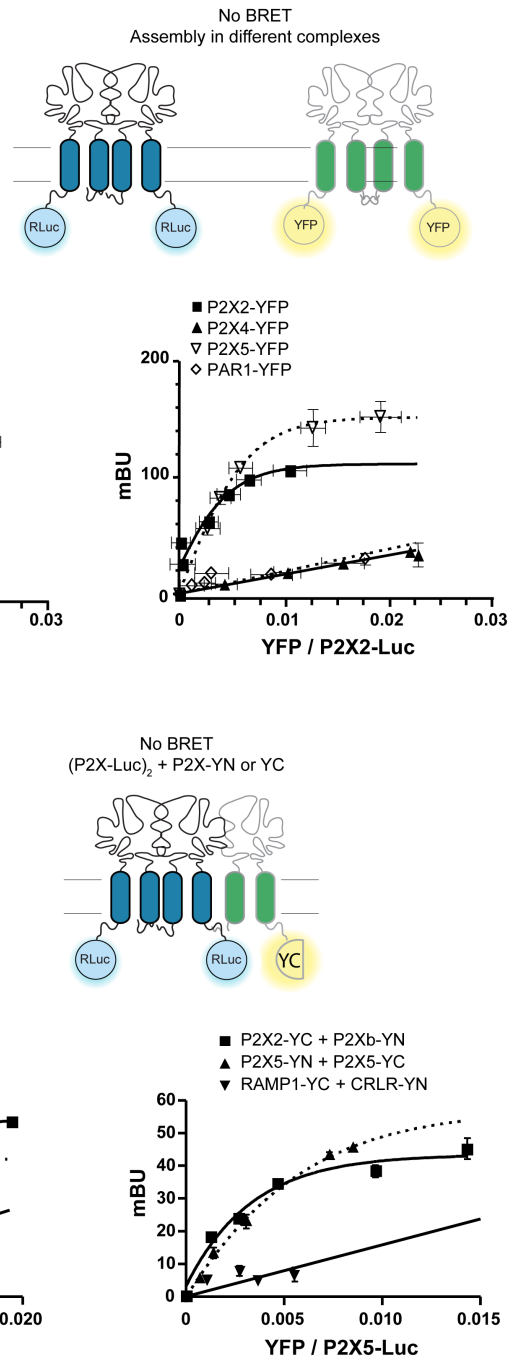

Figure 1: Analysis of $P 2 X$ receptor quaternary structure using BRET and BiFC approaches. A, Top panel: cartoon illustrating how BRET assay allows to detect assembly of $P 2 X$ subunits within the same complex. For simplicity, P2X receptors are only represented with 2 subunits. Bottom panel: BRET titration curves using P2X5-Luc or P2X2-Luc as the energy donors. HEK cells were cotransfected with a constant amount of donor and with an increasing amount of YFP fusions. BRET signals are plotted against the relative amounts of each tagged subunit. Specific, saturating, BRET signals are observed between $P 2 X 5$ / P2X5, P2X2 / P2X2 or P2X5 / P2X2 subunits, while low linear BRET is obtained between $P 2 X 2$ (or P2X5) and PAR-1 or between P2X2 and $P 2 X 4$. Data are expressed as mean $\pm S E M$ of at least $N=3$ experiments. $\boldsymbol{B}$, Top panel: cartoon illustrating how combination of BRET and BiFC assays can be employed to reveal the stoichiometry of heteromeric $P 2 X$ receptors. Bottom panel: BRET titration curves between P2X2-Luc (left) or P2X5-Luc (right) cotransfected with $P 2 X 2, P 2 X 5, R A M P 1$, and $C R L$ receptor fused to hemi-YFP. Specific BRET signals were observed between $P 2 X 2$ and $P 2 X 5$ subunits in each experimental condition, demonstrating the existence of heteromeric receptors with two different stoichiometries. Data are expressed as mean \pm SEM of at least $N=3$ experiments.

\section{References}

1. Wampler JE, Hori K, Lee JW, Cormier MJ (1971) Structured bioluminescence. Two emitters during both the in vitro and the in vivo bioluminescence of the sea pansy, Renilla. Biochemistry 10

(15):2903-2909

2. Ward WW, Cormier MJ (1979) An energy transfer protein in coelenterate bioluminescence. Characterization of the Renilla green-fluorescent protein. J Biol Chem 254 (3):781-788 
3. Young MT, Fisher JA, Fountain SJ, Ford RC, North RA, Khakh BS (2008) Molecular shape, architecture, and size of $\mathrm{P} 2 \mathrm{X} 4$ receptors determined using fluorescence resonance energy transfer and electron microscopy. J Biol Chem 283 (38):26241-26251. doi:10.1074/jbc.M804458200 4. Fisher JA, Girdler G, Khakh BS (2004) Time-resolved measurement of state-specific P2X2 ion channel cytosolic gating motions. J Neurosci 24 (46):10475-10487. doi:10.1523/JNEUROSCI.325004.2004

5. Khakh BS, Fisher JA, Nashmi R, Bowser DN, Lester HA (2005) An angstrom scale interaction between plasma membrane ATP-gated P2X2 and alpha4beta 2 nicotinic channels measured with fluorescence resonance energy transfer and total internal reflection fluorescence microscopy. J Neurosci 25 (29):6911-6920. doi:10.1523/JNEUROSCI.0561-05.2005

6. Limapichat W, Dougherty DA, Lester HA (2014) Subtype-specific mechanisms for functional interaction between alpha6beta4* nicotinic acetylcholine receptors and P2X receptors. Mol Pharmacol 86 (3):263-274. doi:10.1124/mol.114.093179

7. Shrivastava AN, Triller A, Sieghart W, Sarto-Jackson I (2011) Regulation of GABA(A) receptor dynamics by interaction with purinergic P2X(2) receptors. J Biol Chem 286 (16):14455-14468. doi:10.1074/jbc.M110.165282

8. Richler E, Chaumont S, Shigetomi E, Sagasti A, Khakh BS (2008) Tracking transmitter-gated P2X cation channel activation in vitro and in vivo. Nat Methods 5 (1):87-93. doi:10.1038/nmeth1144 9. Koshimizu TA, Kretschmannova K, He ML, Ueno S, Tanoue A, Yanagihara N, Stojilkovic SS, Tsujimoto $G$ (2006) Carboxyl-terminal splicing enhances physical interactions between the cytoplasmic tails of purinergic P2X receptors. Mol Pharmacol 69 (5):1588-1598.

doi:10.1124/mol.105.019802

10. Compan V, Ulmann L, Stelmashenko O, Chemin J, Chaumont S, Rassendren F (2012) P2X2 and P2X5 subunits define a new heteromeric receptor with P2X7-like properties. J Neurosci 32 (12):42844296. doi:10.1523/JNEUROSCI.6332-11.2012 